\title{
O DESENVOLVIMENTISMO NA CRÍTICA DE MÁRIO PEDROSA
}

\author{
Josnei Di Carlo
}

RESUMO: O crítico de arte e socialista Mário Pedrosa (1900-1981) foi um opositor implacável do desenvolvimentismo. Posicionava-se contra o modelo econômico vigente no Brasil desde 1945. Com o Golpe de 1964, esse modelo entrou em crise e passou a ser avaliado criticamente pela esquerda. Nisso, Pedrosa sistematizou sua crítica no interior de $A$ Opção Imperialista e Opção Brasileira, publicados em 1966 pela Civilização Brasileira. Ao tentar compreender a crise política e social envolta no golpe de Estado, defendeu que o projeto desenvolvimentista desvinculou as transformações econômicas da dinâmica social. E, ao esboçar as Reformas de Base, que alterariam as relações capitalistas, tanto entre as classes sociais quanto entre o capital nacional e o capital estrangeiro, João Goulart sofreu a reação da burguesia nacional, apoiada pelos interesses dos Estados Unidos e executada pelos militares.

Palavras-chave: Mário Pedrosa; Golpe de 1964; desenvolvimentismo; Celso Furtado.

\section{DEVELOPMENT IN MÁRIO PEDROSA'S CRITICISM}

ABSTRACT: The art critic and socialist Mario Pedrosa (1900-1981) was a ruthless opponent of developmentalism. It was against the economic model in force in Brazil since 1945. With the 1964 Coup, this model went into crisis and came to be critically evaluated by the left. In this, Pedrosa systematized his critique within A Opção Imperialista and A Opção Brasileira, published in 1966 by the Civilização Brasileira. In trying to understand the political and social crisis involved in the coup, he argued that the developmentalist project dissociated the economic transformations from the social dynamics. And in drafting the Reformas de Base that would alter capitalist relations, both between social classes and between national capital and foreign capital, João Goulart suffered the reaction of the national bourgeoisie, supported by the interests of the United States and executed by the military.

Keywords: Mário Pedrosa; 1964 Coup; developmentalism; Celso Furtado.

\footnotetext{
${ }^{1}$ Bacharel e licenciado em Ciências Sociais pela Universidade Estadual de Londrina (UEL), em 2006, com especialização em Ensino de Sociologia, em 2010, na mesma instituição de ensino superior. Mestre em Ciência Política pela Universidade Federal de São Carlos (UFSCar), em 2013. Doutor em Sociologia Política pela Universidade Federal de Santa Catarina (UFSC), em 2018. Atualmente, é pesquisador do Laboratório de Sociologia do Trabalho (LASTRO/UFSC). Endereço Eletrônico: josneidicarlo@ hotmail.com.br.
} 


\section{EL DESARROLLO EN LA CRÍTICA DE MÁRIO PEDROSA}

RESUMEN: El crítico de arte y socialista Mário Pedrosa (1900-1981) fue un opositor implacable del desarrollismo. Se colocó contra el modelo económico vigente en Brasil desde 1945. Con el Golpe de 1964, ese modelo entró en crisis y pasó a ser evaluado críticamente por la izquierda. En eso, Pedrosa sistematizó su crítica en el interior de A Opção Imperialista y $A$ Opção Brasileira, publicados en 1966 por la Civilização Brasileira. Al intentar comprender la crisis política y social envuelta en el golpe de Estado, defendió que el proyecto desarrollista desvinculó las transformaciones económicas de la dinámica social. Y, al esbozar las Reformas de Base, que cambiarían las relaciones capitalistas, tanto entre las clases sociales como entre el capital nacional y el capital extranjero, João Goulart sufrió la reacción de la burguesía nacional, apoyada por los intereses de Estados Unidos y ejecutada por los militares.

Palavras Clave: Mário Pedrosa; Golpe de 1964; desarrollismo; Celso Furtado.

\section{Introdução}

Mário Pedrosa, em 1966, apreendeu o desenvolvimentismo para além das especificidades da política econômica do modelo de substituição de importações. O processo de industrialização, ao encontrar obstáculos na estrutura social, teve de propor reformas estruturantes para a acumulação capitalista da indústria continuar se expandindo, mas, por mais que as transformações estruturais beneficiassem a burguesia industrial, alterariam a estrutura social no qual ela se originou. As Reformas de Base, propostas no Governo João Goulart (1961-1964) - tendo como principal articulador o ministro do planejamento, Celso Furtado -, tiveram como medida mais contestada a reforma agrária. Seus idealizadores julgavam que ela seria bem aceita pela burguesia industrial, que reconhecia a ineficiência da industrialização, entretanto não via o latifúndio como obstáculo à industrialização. Para a burguesia industrial, o mercado consumidor não se resolvia com a reforma agrária e com a elevação da renda dos trabalhadores, em total oposição à visão desenvolvimentista que a via como classe progressista.

O dualismo a opor burguesia industrial progressiva e burguesia agrária conservadora era anterior à consolidação do desenvolvimentismo como política econômica do Estado brasileiro. Vinha de antes, da esquerda comunista, tendo como críticos mais destacados os militantes da Oposição de Esquerda, liderada por Mário Pedrosa. Fundado em 1922, o Partido Comunista Brasileiro (PCB) fez valer sua interpretação a respeito da formação social do Brasil perante a esquerda desde o início. Agrarismo e Industrialismo, de Octávio Brandão, publicado em 1926, é o marco inicial da teoria pecebista. O título do livro parece indicar relação entre os dois termos, mas trata-se de uma visão dualista sobre o país, pois a 
transformação socialista requer a superação do feudalismo, identificado no setor agrárioexportador: "são dois mundos que se chocam: o feudalismo e o industrialismo. O industrialismo despedaçará o feudalismo. E o comunismo despedaçará o industrialismo burguês", afirma Brandão (2006, p. 47). Os interesses econômicos delimitam as classes burguesas como antagonistas e circunscrevem a origem feudal da burguesia agrária e a origem capitalista da burguesia industrial. Dada a luta de classes, o operariado deve aliar-se ao "industrialismo".

Militante comunista desde 1926, Mário Pedrosa - ao publicar o ensaio "Esboço de Análise da Situação Brasileira" com Lívio Xavier, em 1931 - voltou-se contra o dualismo, ao conceber que a burguesia tinha nascido no campo ${ }^{2}$. Sua afirmação, decorrente do modo como ele apanhou as especificidades do processo histórico, traz em seu bojo diferenças fundamentais em relação à oposição feudalismo versus capitalismo e o levou a conceitualizar revolução democrática burguesa e socialismo de modo diverso do $\mathrm{PCB}$, enriquecendo o marxismo brasileiro anterior à década de 1970, quando a interpretação dualista da formação social passa a ser sistematicamente contestada. Em 1966, com a publicação dos livros $A$ Opção Imperialista e A Opção Brasileira, Pedrosa (1966a; 1966b) aprofundou os conceitos utilizados no documento da Liga Comunista Internacionalista de 1931, redigido em outubro do ano anterior, com a Revolução de 1930 em andamento. Passado três décadas, além de o dualismo permanecer hegemônico no PCB, definindo a política de alianças do operariado com a burguesia industrial, também estava presente no modelo de substituição de importações, surgido nos anos 1950, que orientou a política econômica de vários governos até o Golpe de 1964. Pedrosa analisou criticamente o desenvolvimentismo, apanhando suas contradições e limitações, crítica raramente empreendida à esquerda até aquele momento. Ao realizá-la, além de apanhar as questões puramente econômicas, compreendeu os desdobramentos político e ideológico do desenvolvimentismo em relação às classes sociais e ao modo como elas se articulavam com o desenvolvimento do capitalismo no Brasil sob o capitalismo monopolista, regido pelo capital financeiro de origem estadunidense.

\section{O desenvolvimentismo e Mário Pedrosa}

As primeiras análises sobre a formação socioeconômica brasileira surgiram com a acumulação capitalista do país do pós-guerra e as investigações da dinâmica econômica partiram dos técnicos dos organismos estatais. Celso Furtado, o mais destacado deles, na

\footnotetext{
2 Apesar de nossa fonte ter sido a versão de 1987, que fez o ensaio ficar conhecido como "Esboço de uma Análise da Situação Econômica e Social do Brasil”, usamos seu título original atribuído por Di Carlo (2018).
} 
década de 1950, ao lançar "as primeiras tentativas bem sucedidas de representar a economia brasileira em sistemas conceituais mais complexos e abrangentes" (MANTEGA, 1984, p. 77), possibilitou, continua Mantega (1984, p. 77; p. 87), “a economia política brasileira [...] a existir efetivamente, enquanto ciência sistemática e abrangente, munida de um arcabouço teórico específico para interpretar a dinâmica da economia brasileira". Para Furtado - assim como para Mário Pedrosa, apesar das diferenças teóricas -, o processo periférico não seguia inevitavelmente as etapas do capitalismo central e estava sendo implantado sob forças produtivas e relações capitalistas de produção já avançadas (OLIVEIRA, 2003b). Os dois problemas evidenciavam o avanço do capitalismo no Brasil como um processo de substituição de importações. Identificando a transição da economia agrária para a industrial, construiu a teoria do subdesenvolvimento (MANTEGA, 1984).

Segundo Oliveira (2003a), Celso Furtado surgiu no vazio da produção marxista, com o método histórico-estrutural, se afastando do método neoclássico, por suas necessidades de historicizar a formação das sociedades subdesenvolvidas. "É absurdo apontá-lo como neoclássico, marxista, keynesiano, rótulos que frequentemente lhe dão. Ele tira de cada autor ou corrente o que é, a seu ver, correto ou adaptável à realidade brasileira”, na definição mais direta de Iglésias (1971, p. 176). Furtado, portanto, abandonou a reiteração do colonialismo, em que havia caído o marxismo, destacadamente o que se tornou hegemônico no PCB, tendo como dissidente Mário Pedrosa. Negou o esquema de divisão internacional do trabalho, inspirado na teoria das vantagens comparativas de David Ricardo, que passou a ser, na sua teoria, afirma Oliveira (2003a, p. 12), “desvantagens reiterativas". Caracterizou os países da América Latina como produtores e exportadores de bens primários, enquanto os países centrais do capitalismo, produtores e exportadores de manufaturados, gerando o "mecanismo de sucção do excedente econômico latino-americano por parte das economias dos países centrais" (OLIVEIRA, 2003a, p. 12).

Entre os anos 1950 e 1960, com Formação Econômica do Brasil (1959) e Desenvolvimento e Subdesenvolvimento (1961), Celso Furtado deu corpo à interpretação do subdesenvolvimento. Os subsídios foram adquiridos, em grande parte, durante os oito anos em que dirigiu a Divisão de Desenvolvimento da Comissão Econômica para a América Latina (CEPAL), entre 1949 e 1957. Em Formação Econômica do Brasil, Furtado (2007) analisou a transição do capitalismo agroexportador para o capitalismo industrial, voltado para o mercado interno. A atividade cafeeira foi capaz de mobilizar os recursos econômicos do início do século XIX para dominar a pauta das exportações brasileiras até a metade do século XX. Mas 
somente com a abolição da escravatura as bases da industrialização foram lançadas, em decorrência da incorporação da mão-de-obra livre. O trabalho assalariado, de acordo com Mantega (1984, p. 80), levou a "monetarização das atividades econômicas".

O deslocamento do eixo dinâmico ocorreria quando o parque industrial se diversificasse a ponto de produzir máquinas e equipamentos fundamentais à sua própria expansão. Após a década de 1920, a economia brasileira caminhou nesse sentido, porém a expansão industrial não foi suficiente para consolidar o desenvolvimento autossustentado, até a década de 1960, levando ao esgotamento do desenvolvimentismo, como apontou Pedrosa (1966a; 1966b) ao analisar o Golpe de 1964. Conforme Singer (1968, p. 125), o "fator primário de desequilíbrio" era o setor externo, a elevar o nível dos preços. A política de substituição de importações criou o paradoxo de "quanto mais se substituir importações, tanto mais aumenta a procura de produtos importados", pois, "enquanto determinada manufatura de consumo [...] é importada, o seu preço elevado limita a procura interna. Depois que é produzido no país, com elementos importados, a quantidade procurada aumenta mais que o seu índice de "nacionalização"” (SINGER, 1968, p. 126).

Para Celso Furtado, os países subdesenvolvidos se industrializavam perante um sistema capitalista mundial desenvolvido e tinham mercado e capitais para suas atividades primário-exportadoras, só que não apreendeu as transformações do capitalismo monopolista cuja transição, ocorrida no entreguerras, foi identificada por Lenin (1977) em $O$ Imperialismo: Fase Superior do Capitalismo e o próprio Pedrosa (1966a), destacadamente em A Opção Imperialista. A indústria produzia mercadorias semelhantes às dos países capitalistas desenvolvidos, importando os meios de produção. A industrialização via substituição de importações empregava e pagava pouco e era incapaz de criar seu próprio mercado interno. Situação agravada com a instalação de empresas monopolistas, com tendência a capacidade ociosa e preços elevados, acentuando a concentração de renda e a atrofia do mercado interno. Pedrosa compreendeu que o processo se esgotou nos anos 1960, esgotamento responsável pela aguda crise política enfrentada pelo Governo João Goulart até sua deposição pelos militares, apoiados internamente pelas classes burguesas e médias brasileiras, enquanto o apoio externo tinha sua origem no capital financeiro internacional, principalmente o estadunidense, em defesa de seus interesses econômicos.

Além do problema urbano-industrial, havia a estrutura agrária a agravar a estagnação da economia brasileira. Em Um Projeto para o Brasil (1968), Celso Furtado apontou "a necessidade de se corrigir a deformação estrutural da economia brasileira refletida no perfil da 
demanda, que tem levado ao mau aproveitamento dos recursos produtivos do país" (MANTEGA, 1984, p. 85-86), a importância da reforma agrária para elevar a produtividade e o nível de vida rural e, por fim, a físcalização das empresas estrangeiras, prescrevendo "a fórmula cepalina” de Estado planejador da economia. Reformas profundas, capazes de alterar o status quo e reconfigurar a participação das classes sociais no poder, não poderiam, conforme Mário Pedrosa, ser realizadas como medidas governamentais, de uma racionalidade técnica-econômica, aceitas passivamente pelas classes sociais que veriam a estrutura econômica que a sustentavam abaladas.

A contribuição de Celso Furtado para a formação da economia política brasileira foi fundamental: lançou os alicerces do modelo de substituição de importações. Em Desenvolvimento e Subdesenvolvimento e Dialética do Desenvolvimento (1964), apresentou seus conceitos básicos. O mais importante deles é o de desenvolvimento econômico. Não se deve reduzi-lo à acumulação de capital, o progresso econômico da sociedade também encontra-se em seu bojo. É o que ocorreu nos países capitalistas avançados. Os aumentos de produtividade determinaram o desenvolvimento econômico. A chave dele encontra-se, afirma Mantega (1984), no excedente econômico, cuja conotação é distinta do conceito de Marx. Excedente econômico, na teoria furtadiana, designa a diferença entre o produto bruto e as necessidades de vida de todos aqueles ligados à produção. Retomou a conceitualização dos clássicos, genérica, por não determinar sua origem (trabalho ou capital) e seu caráter social específico (mais-valia, renda da terra etc.), opondo-se à teoria do valor de Marx. O excedente é fruto do capital, pois ele fornece os recursos de investimento, e não do trabalho. Para Marx, o capital é trabalho passado acumulado. Furtado considera a força de trabalho um dos fatores de produção, ao lado do capital.

A exploração é um conceito estranho a sua teoria. Só possível de ser operado caso os salários dos trabalhadores fossem reduzidos abaixo das necessidades de subsistência. Daí decorre as indefinições de Furtado, para responder às questões da participação de cada classe na produção e do quinhão de cada uma dela na produtividade, recorreu aos conceitos da economia neoclássica e afastou-se do conceito de produto líquido, que ele mesmo adotara, ressalta Mantega (1984). O exame dos conceitos chaves de Furtado revela sua indecisão entre duas escolas econômicas irreconciliáveis, a clássica e a neoclássica. A consequência foi a indefinição do papel das classes sociais sob o capitalismo. Não quer dizer que sua análise não é classista, só que ele está preocupado com "a possibilidade de conciliação e de interesses comuns entre as duas classes fundamentais" (MANTEGA, 1984, p. 90), preocupação que 
levou Pedrosa a identificar suas limitações, que se encontram mais em sua ideologia que em suas análises econômicas.

\title{
3. A crítica pedrosiana: o Golpe de 1964 e o esgotamento do desenvolvimentismo
}

Mário Pedrosa identificava dois pontos críticos fundamentais no modelo de substituição de importações: o político e o ideológico. Eles decorriam da leitura burocrática acerca da sociedade civil, de desligar as transformações econômicas da dinâmica social, ao pretender fazer reformas estruturantes em nome das classes sociais, não levando em conta que elas se assentavam sob a estrutura socioeconômica:

\begin{abstract}
A fragilidade do desenvolvimentismo não estava nas análises de seus economistas, estava sobretudo nos equívocos - em muitos deliberados - de sua política e acima de tudo de sua ideologia. Tudo se passava nos vértices da burocracia, nos gabinetes ministeriais, nos conciliábulos políticos, na fraseologia dos teorizantes. Os burocratas e técnicos apegados ao poder do Estado acreditaram que podiam substituir as classes sociais dominantes no seu dinamismo e representá-las e agir, no uso e gozo do poder, em nome delas (PEDROSA, 1966b, p. 227).
\end{abstract}

Só que as burguesias preferiam representar seus interesses diretamente, não precisavam de intermediários, de funcionários públicos, por mais brilhantes que fossem, como era o caso de Celso Furtado, a ocupar cargos em organismos estatais ditando modelos econômicos que possivelmente ampliariam a acumulação capitalista, beneficiando não só a elas, destacadamente a burguesia industrial, no qual o modelo de substituição de importações acreditava beneficiar, como os trabalhadores urbanos e rurais. "A burguesia [...] não tem por hábito deixar-se representar por alguma camada especial de dirigentes, a não ser na época do despotismo esclarecido, quando ainda não era classe dominante" e, conclui Pedrosa (1966b, p. 227), "os burocratas desenvolvimentistas pensaram substituí-la até o fim, sem trauma, sem tropeços".

O núcleo ideológico do burocratismo desenvolvimentista era a conciliação de classes, "um contrato tácito, não escrito, uma espécie de convênio" (PEDROSA, 1966b, p. 169), cuja origem provinha do Estado Novo, mas, enquanto Getúlio Vargas contava com seu carisma, os teóricos do modelo de substituição de importações julgavam que a força de suas ideias bastava para o Estado controlar o processo social e político:

Chegar à plena circularidade de um processo automático, que levaria, no plano teórico, à superação da substituição das importações e a alcançar a plena capacidade para importar, é uma coisa; mas não levar em conta o processo social e político vivo das classes em jogo era outra. A base social sobre que se apoiava o desenvolvimentismo era um compromisso híbrido entre interesses burgueses agrários, interesses rurais, interesses industriais, interesses das classes trabalhadoras, 
classes camponesas - e interesses financeiros internacionais. Sua fragilidade não podia surpreender. Furtado sonhou que felizes circunstâncias de intercâmbio e outras também felizes acabassem levando a "superar a barreira para importar", como se atravessa a barreira do som. Mas para a travessia perigosa ele mesmo nos ensinou que seriam necessárias medidas revolucionárias, a começar pela suspensão dos serviços das dívidas externas, expropriações anti-imperialistas, reforma agrária, gigantescos investimentos pelo Estado, plano global. Já não eram medidas de compromisso, de ordem técnica, mas medidas que envolviam uma política econômica de longo alcance, capaz de alterar o sistema em curso no Brasil, o papel do Estado no sistema, a composição social dos governantes. Para uma tal realização já não bastavam conciliábulos técnicos, nem acordos de vértice, mas requeriam a participação efetiva de forças sociais profundas; ao cabo de todo o processo não estaria seguro que a própria burguesia ainda estivesse com o seu futuro a coberto de uma substituição também (PEDROSA, 1966b, p. 227-228).

A análise de Oliveira (2003b) de que o desenvolvimentismo foi a ideologia própria do chamado período populista assemelha-se, de certa forma, à crítica de Mário Pedrosa, de que a crise do modelo de substituição de importações foi fruto do esgotamento do populismo. A eleição de Jânio Quadros, em 1960, pela coligação envolvendo Partido Trabalhista Nacional (PTN), União Democrática Nacional (UDN), Partido Democrata Cristão (PDC), Partido Libertador (PL) e Partido Republicano (PR), marcou a derrocada da aliança Partido Social Democrático (PSD) e Partido Trabalhista Brasileiro (PTB), inaugurada com Getúlio Vargas, que sustentava o populismo. Sua vitória foi contra a aliança populista-burguesa e o Golpe de 1964 foi produto, em parte, dessa cisão:

Antes, porém, de chegar às grandes opções, que deveriam caracterizar o seu
governo, despediu-se a si mesmo. A cunha de transição que deveria ter sido o seu
governo foi removida. A passarela de bambu do parlamentarismo sui generis
lançada às pressas sobre o vazio para permitir ao chefe populista atravessar
pacificamente, legalmente, de um lado para outro a fim de entrar no Planalto tão
pouco resistiu. A fenda que se abria com a renúncia era a fenda na continuidade do
"desenvolvimento" à la JK da chamada burguesia progressista industrialista. "JK
tinha dela", dizia eu ainda em agosto de 1959 (Jornal do Brasil), "as qualidades e os
defeitos. Daí ser ao mesmo tempo entreguista e nacionalista, tinha dela o dinamismo
característico, mas também a inconsequência de atitudes, resultado de uma posição
contraditória. O grupo burguês desenvolvimentista é nacionalista na justa medida,
isto é, até o ponto em que seus interesses colidem com os dos grandes trustes e
interesses industriais e financeiros estrangeiros. Mas nem sempre há colisão. E, por
outro lado, tem consciência de que laços indissolúveis o prendem àquele grupo. Sua
briga com eles é, no fundo, uma briga em família. Exigir, pois, dos nossos burgueses
progressistas nacionalistas que rompam com os irmãos fazendeiros, os exportadores
e os 'entreguistas' e venham para a rua arrastar o povo todo numa luta frontal e
radical com aquele é exigir que façam o haraquiri, que se destruam em benefício de
grupos radicais de pequenos burgueses ou de coisa ainda mais grave" (PEDROSA,
1966, p. 150).

Segundo Mário Pedrosa, a política do modelo de substituição de importações tornouse mais complexa entre 1956 e 1960, pois o Estado passou a financiar projetos do setor 
estrutural e o capital estrangeiro, setores da indústria ${ }^{3}$. A inflação estava no bojo do processo e, aos poucos, perdia sua função estimulante. Era o problema a ser enfrentado pelo Governo João Goulart ${ }^{4}$. Com o parque industrial diversificado, a questão era substituir o financiamento externo pelo nacional. Outro ponto a desequilibrar o sistema era a desigualdade regional. Historicamente o Estado concentrou seus esforços em atender aos interesses das burguesias do Centro-Sul. O Governo Juscelino Kubtischek, através da criação da Superintendência do Desenvolvimento do Nordeste (SUDENE), em 1959, e de investimentos da Petrobras no Nordeste, tentou reverter a situação. Mas o fenômeno da concentração continuou, em decorrência do aumento do emprego nas indústrias ser menor do que o crescimento demográfico. Acentuando ainda mais o desequilíbrio socioeconômico entre as diversas regiões.

O modelo de substituição de importações, afirma Mário Pedrosa, entrou em seu processo de transição. A burguesia industrial, por ter sua origem no campo, não foi capaz de criar um capitalismo nacional, estava voltada para o litoral, de costas para o interior, não se preocupando com o mercado interno. Tal fato decorre das origens históricas do capitalismo no Brasil, introduzido de fora (metrópole) para dentro (colônia). As forças produtivas dos países subdesenvolvidos não são autorreguláveis, articulam-se com os países desenvolvidos. As burguesias destes usaram "o produto acabada da velha classe na matéria-prima da nova" (PEDROSA, 1966b, p. 292).

A burguesia estadunidense, em seu contexto, criou a igualdade de oportunidade, mas aos poucos institucionalizou a oligarquização do Poder. A oligarquia é que determina a política econômica do Estado: "Fundado nesses privilégios, governa sobre os outros homens de seu e de muitos outros países, determinando uma política econômica para a sua sociedade, o seu Estado e satélites, enquanto não a determina para o mundo todo" (PEDROSA, 1966b, p. 293). A institucionalização do poder da burguesia não ocorreu nos países subdesenvolvidos. E

3 "Durante o Governo de Kubitschek, que expressava os anseios da burguesia cosmopolita, o regime econômico brasileiro, conjugando favores fiscais e de diversos tipos às dificuldades de importação de bens de consumo, funcionou de modo a atrair e a forçar empresas estrangeiras a investirem no país. De um lado, o dispositivo de proteção às manufaturas com similar nacional as compelia a produzirem no Brasil, a fim de não perderem o mercado, o que antes suas matrizes exportavam. Do outro, não apenas Kubitschek lhes concedia vantagens, isenções e privilégios, facultando a formação de monopólios e oligopólios, como a Instrução 113, revitalizada pela Lei de Tarifas, permitia que elas importassem máquinas e equipamentos obsoletos, valorizados como se novos fossem, sem cobertura cambial ou restrição de qualquer espécie quanto aos similares de fabricação nacional, ao tempo em que negava o mesmo direito às firmas brasileiras" (BANDEIRA, 1983, p. 18).

4 "O Plano Trienal destaca a inflação como sendo, depois do desenvolvimento, a característica mais importante da economia brasileira. Nos últimos 15 anos os preços se elevaram em média 16,5\% por ano. Esta média é de 24\%, no entanto, nos últimos 5 anos (1957-1961), o que mostra que a inflação se intensifica progressivamente" (SINGER, 1968, p. 107-108). 
a burguesia se viu no meio de dois antagonismos: o proletariado lutando pelas necessidades sociais e a oligarquia imperialista impondo suas prioridades.

A burguesia cafeeira de São Paulo foi a adversária da Revolução de 1930. Como os produtos para exportação não se diversificaram, Getúlio Vargas teve de conciliar, mantendo o controle sobre ela através do câmbio. Ele tirou a hegemonia dela, ao fazê-la perder o instrumento de seu poder econômico (cf. MARTINS, 1964). Não havia conflito entre as classes dominantes, elas eram fundadoras da nação brasileira. O Golpe de 1964 evidenciou a união entre a burguesia agrária e a burguesia industrial.

Celso Furtado, em Dialética do Desenvolvimento, destaca Pedrosa (1966b, p. 226), reconheceu a "falência de toda a ideologia do desenvolvimento", ao sustentar que a industrialização não formou capital autônomo do setor externo. Também assinalou o primeiro gargalo da economia como sendo o das importações condicionando o investimento, "a mera transferência de tecnologia, isto é, trabalho morto externo, potencializa enormemente a reprodução do capital", nos termos de Oliveira (2003b, p. 76-77, grifos no original). O Governo João Goulart se chocou com o impasse, a ditadura civil-militar, comandada pelo Marechal Castelo Branco, tornou o empecilho política econômica de Estado, ao abdicar do desenvolvimento autônomo, ao deixar para o capital estrangeiro, principalmente o estadunidense, conduzir a economia brasileira.

O Plano Trienal do Governo João Goulart e o Plano de Ação Econômica do Governo (PAEG) da ditadura civil-militar refletiam, de acordo com Mário Pedrosa, os grupos sociais ao qual eles queriam atender. $\mathrm{O}$ fracasso do primeiro era o fracasso do desenvolvimentismo, o do segundo, seria do entreguismo. O PAEG era similar ao Plano Trienal, com uma diferença, a política salarial, o custo da produção seria reduzido impedindo o aumento do salário, demonstrando que a ditadura militar não tinha compromissos com o Brasil:

O Plano Trienal do governo deposto e o Plano de Ação Econômico do governo que
o sucedeu são expressões de dois grupos diferentes, social e politicamente. Um era
expressão de um governo débil, mas impelido pelas bases populares, que mal
representa, a reformas necessárias à estrutura do país. O outro é expressão de um
governo forte, que representou ao ascender os interesses globais da burguesia
brasileira e de grande parte de suas classes médias, além dos interesses da política
imperialista americana neste país. A política jacente de cada plano é típica das bases
sociais de um ou de outro governo (PEDROSA, 1966b, p. 251).

As classes burguesas são imediatistas. A partir da Segunda Guerra Mundial, as burguesias estadunidenses, temerosas de perderem sua dominação social, resolveram aumentar sua participação no poder político, resultando na ideologia da Guerra Fria, de que o 
capitalismo de empresa privada era superior a qualquer outra forma de estatização econômica. A ditadura civil-militar institucionalizou a ideologia:

\begin{abstract}
Partindo da divisão do mundo em "Ocidente" e "Oriente", opondo como duas categorias absolutas "capitalismo" e "comunismo", essa esquematização serviu admiravelmente aos interesses das grandes corporações que exigiram, a partir do fim da guerra, numa pressão cada vez maior sobre a Casa Branca, a mudança da política externa de seu país no sentido de atender agressivamente àqueles interesses. Defender o regime da chamada livre empresa privada, ou a supremacia dos interesses privados como norma para resolver todos os complicados problemas de desenvolvimento social e econômico (e, ao cabo, cultural e político) do seu e dos outros países, eia a essência da política externa dos Estados Unidos, desde a abertura da "guerra fria" (PEDROSA, 1966b, p. 71).
\end{abstract}

Os fenômenos da revolução democrática burguesa incompleta e da estrutura agrária estática, que criavam entraves para a acumulação capitalista da indústria, tinham duas consequências para Mário Pedrosa: 1) a agricultura de exportação, 2) a produção capitalista para satisfazer a população urbana. Entretanto, parte do lucro industrial era transferido para os latifundiários. A terra, por sua vez, mesmo mantendo relações sociais pré-capitalistas, entre o dono e o trabalhador, adentrou na lógica da produção capitalista, tornou-se capital fixo.

Os desenvolvimentistas não compreenderam o processo de introdução da propriedade fundiária no capitalismo brasileiro. "O tipo social do burguês dominante no Brasil é o bifrontal, como uma personagem mítica: ele é proprietário de terra, de um lado, e do outro é proprietário de capital", afirma Pedrosa (1966b, p. 231). Celso Furtado acreditou que a burguesia agrária e a burguesia industrial eram antagônicas, esqueceu que a consciência delas era reativa frente aos interesses da classe trabalhadora, em defesa da propriedade privada.

Conforme Mário Pedrosa, a falência de comando das organizações políticas das classes dominantes no Brasil levou ao Golpe de 1964. Elas não souberam lidar com a inflação de modo técnico-econômico, pois a inflação tinha uma função sócio-política para elas: auferir lucros pelo fato do aumento dos produtos ser mais rápido do que o aumento dos salários e o aumento das matérias-primas. Quando a classe trabalhadora cansou de pagar o preço da inflação e organizou greves, a burguesia industrial se voltou contra o governo. A população urbana aumentou consideravelmente a partir da década de 1940. Como o emprego também era maior nas regiões adiantadas, o desequilíbrio regional se acentuou ainda mais. A urbanização, claro, influiu na luta salarial, pois a oferta de mão de obra aumentou. A ação coercitiva do Estado surgiu para vencer a resistência do proletariado urbano. 
O processo inflacionário, acentuando-se a partir da década de $1930^{5}$, continua Mário Pedrosa, tornou-se o calcanhar de Aquiles do Governo João Goulart, levando as próprias classes burguesas à encruzilhada golpista. Celso Furtado atribuiu à burguesia industrial a responsabilidade pelo fracasso do desenvolvimentismo, por ela ter se encantado pelo clamor dos latifundiários. Esqueceu que só a perspectiva do lucro leva o industrial a construir indústrias. $\mathrm{O}$ antagonismo entre burguesia industrial e burguesia agrária é conjuntural apenas. A dinâmica do sistema favorecia as duas classes:

\begin{abstract}
Na base de toda ligação entre agrários e industriais, nas condições criadas no Brasil, está uma pressuposição essencial - a preservação da intocabilidade das estruturas agrárias em face de qualquer instituto jurídico novo, principalmente referente à propriedade da terra. Em todas as constituições que a si mesmo se tem dado este país, a vetusta instituição é intocável, a despeito de um ou outro florilégio a respeito dos fundamentos sociais daquele direito. A base dinâmica de todo o acordo essencial dos dois grupos consistiu precisamente num mecanismo de intercâmbio de rendas pelo qual a indústria retirava grande parte delas dos saldos produzidos pelo setor agrícola exportador, utilizando-a na ampliação do mercado interno e no estímulo ao processo acumulativo, o qual, em seguida, voltava, em parte, ampliado pela fecundação da mais-valia, às fontes da primeira apropriação. Esperar daí o surgimento de um conflito fundamental de classes, que alinhasse os industriais contra seus velhos aliados, seus ascendentes, era esperar milagre. A oposição de interesses não existia quanto aos fundamentos essenciais de classe; mas aqui e acolá, ao aparecer, era de natureza local e conjuntural (PEDROSA, 1966b, p. 238).
\end{abstract}

Não era contra o poder imperial que a burguesia industrial se voltaria, ressalta Mário Pedrosa, pois o capital estrangeiro acabou por beneficiá-la. Não adiantou Furtado tentar despertar nela a consciência de que em longo prazo a autonomia a favoreceria: "a classe capitalista industrial é naturalmente associada aos grupos externos nos quais busca solução para problemas de conjuntura" (PEDROSA, 1966b, p. 244). A ditadura civil-militar vem para organizar a associação, através de uma séria de reformas contempladas no PAEG. O capital estrangeiro é indispensável à política econômica dela, o Banco Nacional de Desenvolvimento (BNDE) pretendia entregar o controle acionário das siderurgias às empresas transnacionais. $\mathrm{O}$ Fundo Monetário Internacional (FMI) e o Banco Mundial apresentaram uma saída anterior à Primeira Guerra Mundial: transformar o Brasil em agroexportador - "num sistema que se fundaria numa espécie de modelo projetado de uma Argentina multiplicada por uma Austrália”, na ironia de Pedrosa (1966b, p. 199).

5 "A tendência da inflação permite distinguir três grandes ciclos inflacionários. No primeiro, nas décadas de 1930 e de 1940, a inflação anual partiu de valores negativos no início dos anos trinta, cresceu até o pico de $20 \%$ na Segunda Guerra, e encerrou em 6\%, em 1949. No segundo ciclo, nas décadas de 1950 e de 1960, a inflação anual atingiu o pico de $90 \%$, em 1964, retornando a 16\%, em 1970. No terceiro ciclo, de 1970 a 1995, a trajetória da inflação foi explosiva, culminando em taxas anuais de 2 737\%, em 1990” (IBGE, 2006, p. 514). 
Enfatiza que o Brasil vivia, no início da ditadura civil-militar, um processo de transição, o modelo de substituição de importações mudaria porque "a economia dual brasileira chegou ao impasse" (PEDROSA, 1966b, p. 247). Por ser amplo, o setor de bens de capital poderia contribuir para as inversões econômicas necessárias para o aumento de produtividade do setor primário. Só que a base social da ditadura civil-militar, formada pelas classes burguesas, as classes médias e o capital financeiro estadunidense, não era considerável para levar o processo adiante. Além do mais, as Forças Armadas, assim como as classes dominantes, tinham plena consciência que estavam em área de influência do poder imperial dos Estados Unidos. A política, no Brasil, estava ligada aos interesses estadunidenses. Esta era a "novidade" implantada pelo Golpe de 1964.

Na verdade, a ditadura civil-militar, "burguesa e subimperialista" (PEDROSA, 1966b, p. 248), adia o enfrentamento ante os estrangulamentos externos e se apegou aos investimentos estrangeiros, com mais facilidades para se internalizar pelo país, que "poderá ser dividido em centros estratégicos de poder que permitirão o controle total, econômico e político, do Brasil pelo 'complexo industrial-militar' que governa os Estados Unidos" (PEDROSA, 1966b, p. 249). Ela defendia os interesses estadunidenses, por um lado, e o status quo brasileiro, por outro. Não há mais problemas externos, eles se confundem com a política internacional dos EUA. A burguesia industrial, presa ao capital estrangeiro e à burguesia agrária, tinha o horizonte limitado para conduzir a transição a um novo modelo de desenvolvimento. Não detinha um projeto nacional.

O plano econômico dos países subdesenvolvidos, segundo Mário Pedrosa, devia voltar-se para as necessidades populares, através da criação de um novo tipo de produção, necessária para o desenvolvimento das forças produtivas. Se assim não fosse, tratava-se de um plano de exploração. O jovem capitalismo brasileiro nasceu velho e estava confinado ao eixo Rio-São Paulo, impotente por não ser capaz de investir em infraestrutura, produzia mercadorias para o consumo das classes médias urbanas. Com uma massa de desvalidos à margem da produção, esperando a consciência de classe ser insuflada nela.

"A classe industrial brasileira é culturalmente colonizada como suas congêneres latino-americanas", sustenta Pedrosa (1966b, p. 293). Colonizados como eram, as burguesias latino-americanas tinham o Conselho Interamericano de Comércio e Produção (1941) para defender o capitalismo, não necessariamente de seus países, mas o estadunidense mesmo. As transnacionais não tinham compromissos com os países onde estavam instaladas, seus compromissos eram com a matriz (cf. BANDEIRA, 1983). A ditadura civil-militar clarificou 
os problemas fundamentais do Brasil e a questão da independência econômica. Ela tinha como base "duas dogmáticas apriorísticas" (PEDROSA, 1966b, p. 184): 1) a Guerra Fria como bússola na política internacional, 2) a economia brasileira era incapaz de se desenvolver por si só. Veio para salvar uma ideologia, a do liberalismo, não os brasileiros.

Otávio Gouveia de Bulhões, destaca Pedrosa (1966, p. 183, grifos no original), evidenciava a doutrina financeira de forma mais clara e direta do que Roberto Campos, ao afirmar que os aumentos salariais deveriam ser inferior aos preços e que a redução de consumo tinha caráter pedagógica: "É indispensável sejam (os aumentos salariais) em proporção inferior aos acréscimos dos preços porque essa diferença a menos de poder de compra modifica a mentalidade (sic) dos consumidores e dos produtores". Roberto Campos simbolizaria o governo acima das classes, por ser um representante das finanças internacionais; em outros termos, dos interesses estadunidenses, por ser "um desses técnicos que servem, indistintamente, nas múltiplas instituições financeiras internacionais ligada à ONU e que promovem os interesses dos Estados Unidos" (PEDROSA, 1966b, p. 184). Enquanto o Marechal Castelo Branco, o árbitro sobre as classes.

Os militares não tinham uma política ao dar o Golpe de 1964, de acordo com Mário Pedrosa, mas um estado de espírito. O povo brasileiro, sob a estagnação econômica, esperava a estabilização da moeda. O Marechal Castelo Branco, com seu formalismo burocrático, fez a ditadura perder apoio, "no curto espaço de tempo decorrido desde $1^{\circ}$ de abril de 1964, o ‘poder revolucionário' envelheceu dez anos”, nos termos de Pedrosa (1966b, p. 187). A ditadura civil-militar já cumpriu seu papel fascista ${ }^{6}$, de colocar tudo no seu devido lugar, os trabalhadores urbanos e rurais, as disputas políticas etc.:

\begin{abstract}
A ditadura militar terá feito o papel do "jacobinismo" de marcha à ré que foi o fascismo: o jacobinismo da época da burguesias decadentes, na rampa de descida do curso histórico. Que fez ela de histórico e providencial? Repôs as massas no seu lugar, quebrou-lhes o ímpeto e o sentimento de autoconfiança que iam adquirindo; reprimiu o balbucio de uma conscientização reivindicatória no campo. Dissolveulhes as organizações de resistência, emasculou-lhes os sindicatos, suprimiu os órgãos centrais de representação, que podiam falar em nome dos interesses coletivos da classe trabalhadora no Brasil, fez do direito de greve não um direito para ser exercido mas uma via extrema cheia de ameaças e de condicionamentos, como uma corrida de obstáculos. E os salários são contidos e diminuídos. Com efeito, os serviços por ela prestados são positivos (PEDROSA, 1966, p. 187).
\end{abstract}

6 “o pós-1964 dificilmente se compatibiliza com a imagem de uma revolução econômica burguesa, mas é mais semelhante com o seu oposto, o de uma contrarrevolução. Esta talvez seja sua semelhança mais pronunciada com o fascismo, que no fundo é uma combinação de expansão econômica e repressão" (OLIVEIRA, 2003 b, p. 106). 
Para Mário Pedrosa, o crescimento econômico brasileiro tinha seu estrangulamento no setor externo desde a década de 1930, só que o Governo Getúlio Vargas barganhava com as potências, possibilitando a industrialização e o saldo comercial positivo. Mas com o fim da Segunda Guerra Mundial, os esforços dos Estados Unidos se concentraram em dificultar o balanço comercial dos países da América Latina, entre eles, o Brasil (Cf. ANDRADE, 2017). As sutilezas dos economistas da ditadura civil-militar não deram conta de apreender o desenvolvimento capitalista brasileiro, a dinâmica dos novos grupos sociais, a destacar a burguesia industrial, surgidos com o processo de substituição das importações.

A classe operária brasileira era nova, tinha sua origem no meio rural. Sustentou o populismo, deu apoio a Luís Carlos Prestes e permitiu a vitória inicial de João Goulart, enumera Mário Pedrosa. A ação sindical e a ação política a fizeram reconhecer as instituições democráticas como fundamentais a suas conquistas. Com a restauração da democracia em 1945, lutou pela autonomia sindical e adquiriu uma consciência de classe reformista, "nos moldes de um Estado paternalista bonapartista" (PEDROSA, 1966b, p. 280). A ditadura civilmilitar tentava demolir as bases do reformismo operariado, deixando a consciência de classe em tensão. De imediato, suprimiu as liberdades democráticas e, fazendo uso de todos os meios, interviu nos sindicatos, criando obstáculos aos candidatos oposicionistas. A política sindical do Governo Castelo Branco se clarificou, redução salarial como instrumento de contenção da inflação (Cf. OLIVEIRA, 2003b). Os operários teriam uma vida difícil na ditadura civil-militar. Cabia a eles intervirem na dinâmica social e lutarem pela efetivação da reforma agrária, instrumento para vencer a pressão demográfica.

Mário Pedrosa afirma que por estar vinculado aos interesses imperialistas, as classes burguesas do Brasil não tinham condições de dominar o processo histórico. Fazia-se necessário a formulação de uma nova política de desenvolvimento, um "socialismo combinado", nos termos de Pedrosa (1966b, p. 274), capaz de agregar os trabalhadores das cidades e dos campos, que arrastariam outras classes para "a revolução popular brasileira" (Cf. ANDRADE, 2016).

\section{Conclusão: pressupostos da crítica}

A proposição política do desenvolvimentismo, cerne da teoria da CEPAL e da teoria de Celso Furtado, era industrializar-se. A industrialização, de acordo com Oliveira (2003a), seria a solução de todos os problemas: de um lado, a relação de intercâmbio se modificaria e, 
de outro, sua modificação poria fim à inflação estrutural ${ }^{7}$. Converteu-se em ideologia, determinando políticas concretas, cujo pressuposto era que a acumulação capitalista realizada pela burguesia industrial permitiria a superação do subdesenvolvimento. O modelo de substituição de importações apontava dois setores socioeconômicos: o moderno e o atrasado. Como o antagonismo das classes burguesas se definia pela forma como elas se inseriam na estrutura socioeconômico, bastaria levar a atrofia da burguesia agrária, que se apoiava no atraso, para o Brasil passar a ter um capitalismo moderno, possibilitando o desenvolvimento econômico. O Golpe de 1964 demostrou que o antagonismo das classes burguesas era conjuntural, elas representavam o mesmo projeto de poder e social.

"Esboço de Análise da Situação Brasileira”, através de conceitos do pensamento dialético-marxista, fornece elementos para apreender o dualismo como deslocado das especificidades da formação social brasileira, com sua constatação de que as classes burguesas eram originárias do campo. "A burguesia brasileira nasceu no campo, não na cidade", eram agrário-exportadoras, constatam Pedrosa e Xavier (1987, p. 69). Para eles, as metrópoles exportaram o modo de produção capitalista para as colônias. No intuito de evitar que a terra se tornasse meios de produção para o colono livre, o Estado apropriou-se da terra, introduziu a escravidão, caracterizando a colonização. "Seu caráter de exploração rural colonial precedeu historicamente sua organização como Estado [...] todos vinham explorar a força de trabalho do indígena adaptado e do negro importado", destacam Pedrosa e Xavier (1987, p. 68). Os pequenos proprietários não faziam parte da formação socioeconômica do Brasil. O Estado mantinha-se sob a ampla exploração escravista para a minoria detentora da terra. O regime escravista teve de ser destruído para o desenvolvimento capitalista, necessário à expansão da indústria inglesa.

O desenvolvimento capitalista, continuam Mário Pedrosa e Lívio Xavier, exigiu outra mudança, essencial para o poder ser deslocado para a São Paulo da burguesia cafeeira, a implantação da República. Para ela não ser drástica, a forma federativa foi inevitável. O desenvolvimento da cultura cafeeira era eminentemente capitalista, encontrou as bases necessárias para a monocultura, e fez prosperar, nos termos de Pedrosa e Xavier (1987, p. 72), "o desenvolvimento do capitalismo sob todas as suas formas". Se interiorizando pelo

\footnotetext{
7 “inflação é estrutural num duplo sentido: em primeiro lugar, a contínua deterioração dos preços de intercâmbio entre as economias centrais e as economias latino-americanas obriga estas a aumentarem constantemente a produção em volume físico para compensar a queda dos preços internacionais das mercadorias que exportam; em segundo lugar, a inelasticidade da oferta agrícola de alimentos produzidos pelo 'atrasado' - uma conclusão fundada num aspecto peculiar à economia chilena, o qual ocorre conjunturalmente em alguns outros países latino-americanos - eleva os preços e instaura uma corrida entre preços e salários no setor 'moderno"' (OLIVEIRA, 2003a, p. 14).
} 
território nacional, o capitalismo transformou as bases econômicas retardatárias, tornando o Brasil atraente para o imperialismo. A industrialização complicou as relações de classe, pois a burguesia agrária queria manter o monopólio da produção cafeeira. A fragilidade do mercado interno levou a centralização do poder no governo federal, para a demanda crescer. O imperialismo acelerou e agravou as contradições econômicas e as contradições de classe e as classes burguesas do país, desestabilizando mais do que acomodando esses setores no plano do Estado nacional, porque, segundo Pedrosa e Xavier (1987, p. 74), "não tem bases econômicas estáveis que lhe permitem edificar uma superestrutura política e social progressiva", fazendo brotar seu reacionarismo frente às ameaças da luta de classes proletárias. Pedrosa e Xavier (1987, p. 75) consideram que "a indústria nasce ligada ao Estado pelo cordão umbilical", concomitante com o domínio imperialista dos Grã-Bretanha. Concluem,

Nos países novos, diretamente subordinados ao imperialismo, a burguesia nacional, ao aparecer na arena histórica, já era velha e reacionária, com ideais democráticos corruptos. A contradição que faz com que o imperialismo - ao revolucionar de modo permanente a economia dos países que lhe são submetidos - atue como fator reacionário em política encontra a sua expressão nos governos fortes e na subordinação da sociedade ao poder executivo (PEDROSA; XAVIER, 1987, p. 7475).

A desigualdade do processo histórico era mais evidente e complexo nos países atrasados. Eles tinham de avançar aos saltos, devido à pressão externa. Da lei da desigualdade, outra deriva: a lei do desenvolvimento combinado. Trotsky (1967, p. 25, grifos no original), ao analisar a História da Rússia, assim fala sobre o conceito de desenvolvimento desigual e combinado, essencial no pensamento de Pedrosa, para romper com as teses dualistas sobre o Brasil:

\footnotetext{
As leis da História nada têm em comum com os sistemas pedantescos. A desigualdade do ritmo, que é a lei mais geral do processus histórico, evidencia-se com maior vigor e complexidade nos destinos dos países atrasados. Sob o chicote das necessidades externas, a vida retardatária vê-se na contingência de avançar aos saltos. Desta lei universal da desigualdade dos ritmos decorre outra lei que, por falta de denominação apropriada, chamaremos de lei do desenvolvimento combinado, que significa aproximação das diversas etapas, combinação das fases diferenciadas, amálgama das formas arcaicas com as mais moderna. Sem esta lei, tomada, bem entendido, em todo o seu conjunto material, é impossível compreender a história da Rússia, como em geral a de todos os países chamados à civilização em segunda, terceira ou décima linha.
}

A estrutura da indústria determinava o caráter social da burguesia e a política do país. A concentração industrial levou ao não surgimento de classes intermediárias entre as massas populares e os dirigentes capitalistas. Como o capital das indústrias era estrangeiro, o 
parlamento não era desejado. Mantega (1984) destaca que o parlamento não era controlado pela burguesia industrial, a maior bancada era comandada pela burguesia agrária, além da política ser populista, tomando medidas que iam contra seus interesses, tornando o parlamento obstáculo a impedir sua acumulação. Em 1964, a burguesia industrial notou que dissolver ou manter sob controle o parlamento a favorecia. Portanto, a tese de que ela era progressista se mostrou equivocada. Isolando-a ainda mais, por ser incapaz de realizar reformas. Fraca, era incapaz de mexer na estrutura agrária, por medo de abalar suas próprias estruturas.

Para se vencer o dualismo, a reforma agrária era "o elemento viabilizador da industrialização", porque, de acordo com Oliveira (2003a, p. 14-15, grifos no original), criava mercado interno, aumentava "a oferta de alimentos, desbloqueando a acumulação por impedir o aumento dos salários nominais". A importância do dual-estruturalismo reside no fato de “processos que não eram perceptíveis nem importantes" para o método neoclássico, nem para o etapismo do PCB, tornaram-se objetos de pesquisa, mas também mascarava interesses de classes que se colocavam como nacionais, conforme Oliveira (2003a, p.15, grifo do autor). A economia política de Celso Furtado era produção para a ação. Daí decorria sua limitação e seu caráter ideológico. Mas ainda é uma referência nos estudos sobre o subdesenvolvimento.

A dualidade da teoria do subdesenvolvimento não conseguiu ultrapassar as contradições do moderno e do atrasado do campo da oposição pura, não foi capaz de teorizar a relação entre os dois setores, desenvolveu uma teoria da formação do capital, mas não uma da acumulação (OLIVEIRA, 2003b). No início, Furtado era otimista, como as relações de produção não construíam a sociabilidade, como em Marx, a política na teoria furtadiana era um epifenômeno.

O dual-estruturalismo cepalino-furtadiano não deve ser confundindo com o desenvolvimento desigual e combinado, pois, para Furtado, o desenvolvimento era desigual, mas não era combinado, o moderno e o atrasado não se articulavam, este era apenas um obstáculo aquele. Pedrosa, ao analisar a formação das classes burguesas, notou a articulação entre os dois setores socioeconômicos, levando-o a observar que o desenvolvimentismo, ao acreditar que a burguesia industrial aceitaria de bom grado reformas estruturantes, que alterariam sua base socioeconômica, perdeu uma oportunidade histórica para levar o Brasil a superação do subdesenvolvimento, politizando-o no interior de transformações sociais, que pudessem situar o proletariado e outros segmentos sociais próximos a ele enquanto condutores dessa ruptura. 


\section{Referências}

ANDRADE, Everaldo. Mário Pedrosa e o debate sobre a planificação econômica socialista no Brasil. Diálogos. Maringá: UEM, vol. 20, n. 1, p. 117-135, 2016.

Mário Pedrosa e a construção do espaço imperial dos EUA sob o capitalismo monopolista. Projeto História. São Paulo: PUC, vol. 59, p. 10-42, abr.-jul. 2017.

BANDEIRA, Moniz. O governo João Goulart: as lutas sociais no Brasil (1961-1964). $6^{\text {a }}$ ed. Rio de Janeiro: Civilização Brasileira, 1983.

BRANDÃO, Octávio. Agrarismo e industrialismo: ensaio marxista-leninista sobre a revolta, de São Paulo e a guerra das classes no Brasil. 2ª ed. São Paulo: Anita Garibaldi: 2006.

DI CARLO, Josnei. Da margem se vê melhor? O autoritarismo no Brasil segundo a Oposição de Esquerda nos anos 1930. Política Hoje. Recife: UFPE, vol. 27, Edição Especial, p. 162$194,2018$.

FURTADO, Celso. Formação econômica do Brasil. $34^{\circ}$ ed. São Paulo: Companhia das Letras, 2007.

IBGE. Estatísticas do século XX. Rio de Janeiro: Instituto Brasileiro de Geografia e Estatística, 2006.

IGLÉSIAS, Francisco. Celso Furtado: pensamento e ação. História e ideologia. São Paulo: Perspectiva, p. 159-234, 1971.

LENIN, Vladimir Ilich. O imperialismo: fase superior do capitalismo. In: Obras escolhidas: tomo 1. Lisboa: Avante; Moscou: Progresso, p. 575-671, 1977.

MANTEGA, Guido. A economia política brasileira. $2^{\mathrm{a}}$ ed. São Paulo/Petrópolis: Polis/Vozes, 1984.

MARTINS, Luciano. Aspectos políticos da revolução brasileira. Revista Civilização Brasileira, $\mathrm{n}^{\mathrm{o}}$ 2, p. 15-37, mai. 1965.

OLIVEIRA, Francisco. A navegação venturosa. São Paulo: Boitempo, 2003a.

Crítica à razão dualista. In: Crítica à razão dualista/O ornitorrinco. São Paulo: Boitempo, p. 25-119, 2003b.

Elegia para uma re(li)gião: SUDENE, Nordeste, Planejamento e conflitos de classes. In: Noiva da revolução/Elegia para uma religião: SUDENE, Nordeste, Planejamento e conflitos de classes. São Paulo: Boitempo, p. 119-275, 2008.

PEDROSA, Mário. A opção imperialista. Rio de Janeiro: Civilização Brasileira, 1966a.

A opção brasileira. Rio de Janeiro: Civilização Brasileira, 1966b. 
; XAVIER, Lívio. Esboço de uma análise da situação econômica e social no Brasil. In: KAREPOVS, Dainis; ABRAMO, Fúlvio. (Org.). Na contracorrente da história: documentos da Liga Comunista Internacionalista (1930-1933). São Paulo: Brasiliense, p. 6682, 1987.

SINGER, Paul. Desenvolvimento e crise. São Paulo: Difusão Européia do Livro, 1968.

TROTSKY, Leon. Peculiaridades do desenvolvimento da Rússia. Trad. E. Huggins. In: A História da Revolução Russa: volume 1. Rio de Janeiro: Saga, p. 23-33, 1967.

Recebido em julho de 2018

Aprovado em dezembro de 2018 